\title{
Pengaruh penggunaan angiotensin converting enzyme inhibitor (ACEI) dan angiotensin receptor blocker (ARB) pada pasien coronavirus disease 2019 (covid-19) dengan hipertensi
}

\author{
Briando Linelejan, ${ }^{1}$ Octavianus Umboh, ${ }^{2}$ Frans E. N. Wantania ${ }^{2}$
}

\author{
${ }^{1}$ Program Studi Pendidikan Dokter Fakultas Kedokteran Universitas Sam Ratulangi, \\ Manado, Sulawesi Utara, Indonesia \\ ${ }^{2}$ Bagian Ilmu Penyakit Dalam Fakultas Kedokteran Universitas Sam Ratulangi Manado, \\ Sulawesi Utara, Indonesia \\ Email: briandolinelejan@gmail.com
}

\begin{abstract}
Hypertension is considered as one of the highest death-caused disease worldwide. Coronavirus disease 2019 (COVID-19) pandemic caused by severe acute respiratory syndrome coronavirus 2 (SARS-CoV-2) most frequently occurred in elderly and those who had comorbid diseases, one of them is hypertension. The first line drugs that are usually used in hypertension are angiotensin converting enzyme inhibitors (ACEIs) and angiotensin receptor blockers (ARBs). It is assumed that these drugs coud influence the progress of COVID-19 due to the similiar target receptor. This study was aimed to evaluate the influence of ACEls and ARBs to patients with COVID-19 and hypertension. This was a literature review study using literatures published in medical journal databases such as PubMed and ClinicalKey. The results obtained 10 literatures that fulfilled the inclusion and exclusion criteria. These ten literatures stated that there was no influence of using ACEIs and ARBs in COVID-19 patients. In conclusion, ACEIs and ARBs do not influence the mortality or progresivity of COVID-19 disease and are suggested to be consumed continually.
\end{abstract}

Keywords: ACEIs, ARBs, COVID-19, hypertension, hypertension in COVID-19

\begin{abstract}
Abstrak: Hipertensi merupakan salah satu penyebab kematian tertinggi di dunia. Pandemik coronavirus disease 2019 (COVID-19) dengan severe acute respiratory syndrome coronavirus 2 (SARS-CoV-2) sebagai etiologinya kebanyakan terjadi pada usia tua serta yang memiliki penyakit komorbid, salah satu yang tersering ialah hipertensi. Obat lini pertama yang biasa digunakan untuk hipertensi yaitu angiotensin converting enzyme inhibitor (ACEI) dan angiotensin receptor blockers (ARB) dikatakan dapat memengaruhi perkembangan penyakit COVID-19 karena memiliki reseptor atau tempat kerja yang mirip. Penelitian ini bertujuan untuk mengevaluasi pengaruh penggunaan ACEI dan ARB pada pasien COVID-19 dengan hipertensi. Jenis penelitian ialah literature review dengan menggunakan literatur-literatur yang dipublikasi dalam database jurnal kedokteran PubMed dan ClinicalKey sesuai dengan kriteria inklusi dan eksklusi penelitian. Hasil penelitian mendapatkan 10 literatur; kesemuanya menyatakan bahwa tidak terdapat pengaruh penggunaan ACEI dan ARB terhadap pasien COVID-19. Simpulan penelitian ini penggunaan ACEI dan ARB tidak memengaruhi mortalitas maupun progresivitas penyakit COVID-19 dan disarankan untuk tetap dilanjutkan.
\end{abstract}

Kata kunci: ACEI, ARB, COVID-19, hipertensi, hipertensi pada COVID-19

\section{PENDAHULUAN}

Hipertensi adalah suatu keadaan tekanan darah sistolik diatas atau sama dengan 130 $\mathrm{mmHg}$ dan diastolik diatas atau sama dengan $80 \mathrm{mmHg} .^{1,2}$ Hipertensi dianggap sebagai salah satu penyebab kematian tertinggi di dunia, sering disebut sebagai silent killer. ${ }^{1}$ Coronavirus Disease 2019 (COVID- 
19) merupakan suatu penyakit menular dengan gejala gangguan pernapasan akut dan serbagai agen penyebab ialah Severe Acute Respiratory Syndrome Coronavirus 2 (SARS-CoV-2). ${ }^{3}$

World Health Organization (WHO) telah menetapkan COVID-19 sebagai pandemi sejak tanggal 11 Maret $2020,^{3}$ sedangkan di Indonesia, pada tanggal 2 Maret 2020 pertama kalinya dilaporkan kasus terkonfirmasi COVID-19 dan terus bertambah sampai sekarang. ${ }^{3}$ Kasus terkonfirmasi positif COVID-19 di seluruh dunia sampai pada 30 Agustus 2020 tercatat sebanyak 24.854.140 dengan jumlah kematian sebanyak 838.924 menurut situs resmi WHO. ${ }^{4}$ Indonesia sendiri menurut laman resmi update kasus covid19.go.id untuk total kasus terkonfirmasi positif COVID-19 sampai 31 Agustus 2020 sebanyak 174.796, total kasus meninggal 7.417 dan total yang sembuh 125.959. Provinsi Sulawesi Utara menurut laman corona.sulutprov.go.id total kasus terkonfirmasi positif COVID-19 sebanyak 3.833, total kasus meninggal 156 dan total yang sembuh 2.738 periode 31 Agustus $2020 .^{6}$

Menurut penelitian Huang et $\mathrm{al}^{7}$ penyakit bawaan yang paling sering dilaporkan ialah diabetes (20\%), hipertensi (15\%) dan penyakit kardiovaskuler $(15 \%))^{7,8}$ Frekuensi pasien COVID-19 yang menyandang hipertensi tidak sepenuhnya mengejutkan dikarenakan hipertensi biasanya terjadi pada orang tua, dan orang tua juga merupakan faktor risiko untuk rentan terinfeksi. ${ }^{8}$

Permasalahan bahwa tekanan darah yang tidak terkontrol merupakan suatu faktor risiko terinfeksi COVID-19 atau apakah tekanan darah yang terkontrol merupakan suatu faktor risiko atau bukan pada pasien hipertensi masih belum jelas. ${ }^{8}$ Kontrol tekanan darah dijadikan sebagai pertimbangan untuk mengurangi beban penyakit seperti yang dikemukakan oleh beberapa organisasi. ${ }^{8}$

Hipertensi merupakan komorbid yang paling umum pada pasien COVID-19 yang menerima terapi ventilasi mekanik berdasarkan laporan dari Lombardy, Italy dan New York, Amerika Serikat. ${ }^{9}$ Karena tingginya angka mortalitas pada pasien COVID-19 dengan komorbid hipertensi maka para ahli di seluruh dunia mulai berdebat mengenai penggunaan obat hipertensi dengan mekanisme penghambat sistem renin-angiotensin-aldosteron (SRAA). ${ }^{9}$ Terdapat dua faktor yang berpengaruh terhadap hal tersebut. Pertama, berdasarkan observasi bahwa hipertensi menjadi salah satu komorbid yang paling umum bersamaan dengan pasien COVID-19 kasus berat yang telah dirawat di rumah sakit dan memiliki risiko untuk meninggal. Kedua, telah diteliti bahwa SARS-CoV-2 yang merupakan etiologi dari COVID-19 memiliki tempat pelekatan yang spesifik terhadap angiotensinconverting enzyme 2 (ACE-2) yang banyak terdapat di paru dan jantung. ${ }^{10,11}$

Pasien COVID-19 memang memiliki komorbid tersering hipertensi dan bentuk lain dari penyakit kardiovaskuler. Pada pasien hipertensi sering digunakan terapi penghambat SRAA dalam hal ini angiotensin converting enzyme inhibitor (ACEI) dan angiotensin receptor blockers (ARB), yang kemudian mengundang pertanyaan dari para ahli karena mengingat bahwa SARS-CoV-2 akan mengikat ACE-2 pada paru dan jantung. ${ }^{8}$ Timbul spekulasi bahwa penggunaan obat hipertensi penghambat SRAA secara spesifik ACEI dan ARB dapat meningkatkan pengeluaran ACE-2 pada saluran napas dan akan meningkatkan risiko terinfeksi COVID-19 serta kemungkinan akan berkembang menjadi lebih parah. ${ }^{11}$ Namun ada juga yang menyebutkan bahwa pasien COVID-19 dengan hipertensi yang mengonsumsi ACEI dan ARB sebaiknya diganti dengan obat anti-hipertensi golongan lain dikarenakan informasi yang masih kontroversial. ${ }^{10}$ Berdasarkan latar belakang yang dipaparkan maka penulis tertarik untuk mengevaluasi pengaruh penggunaan ACEI dan ARB pada pasien COVID-19 dengan hipertensi.

\section{METODE PENELITIAN}

Jenis penelitian ini ialah literature review, dilakukan dengan cara identifikasi, evaluasi dan interpretasi terhadap semua hasil penelitian, topik atau fenomena 
tertentu yang menjadi perhatian dalam penelitian ini. Strategi yang digunakan ialah pencarian artikel menggunakan database jurnal kedokteran PubMed dan ClinicalKey dengan kata kunci Hypertension and COVID-19.

\section{HASIL PENELITIAN}

Setelah dilakukan seleksi, didapatkan 10 literatur yang memenuhi kriteria inklusi dan eksklusi penelitian ini dan memiliki variasi dalam jumlah sampel mulai dari puluhan sampai ribuan. Tabel 1 memperlihatkan hasil analisis kesepuluh literatur.

Tabel 1. Perbandingan karakteristik masing-masing literatur

\begin{tabular}{|c|c|c|c|c|c|c|c|c|}
\hline No & $\begin{array}{l}\text { Nama } \\
\text { Author }\end{array}$ & Metode & $\begin{array}{l}\text { Jumlah } \\
\text { Sampel }\end{array}$ & $\begin{array}{l}\text { Pria } \\
(\%)\end{array}$ & $\begin{array}{l}\text { Usia } \\
\text { rerata }\end{array}$ & $\begin{array}{c}\text { Terapi } \\
\text { ACEI/ } \\
\text { ARB } \\
\end{array}$ & Komorbid Lain & Hasil \\
\hline 1 & $\begin{array}{l}\text { Peng } \\
\text { Zhang et al } \\
\text { (Hubei, } \\
\text { Cina) })^{12}\end{array}$ & $\begin{array}{l}\text { Studi } \\
\text { cohort- } \\
\text { retro- } \\
\text { spektif, } \\
\text { multi- } \\
\text { center }\end{array}$ & $\begin{array}{l}- \text { Pasien } \\
\text { COVID-19= } \\
3430 \\
\text { Pasien } \\
\text { dengan } \\
\text { Hipertensi } \\
\text { dan COVID- } \\
19=1128\end{array}$ & 53,5 & 64 & $\begin{array}{l}\text { - } \mathrm{ACEI} / \mathrm{A} \\
\mathrm{RB}= \\
188 \\
\text { - } \mathrm{Non}= \\
940\end{array}$ & $\begin{array}{l}\text { - Diabetes melitus } \\
\text { - Penyakit jantung } \\
\text { koroner } \\
\text { - Penyakit ginjal } \\
\text { kronik } \\
\text { - Penyakit } \\
\text { serebrovaskuler } \\
\text { - Penyakit hati } \\
\text { kronik } \\
\text { - Penyakit paru } \\
\text { obstruktif kronik }\end{array}$ & $\begin{array}{l}\text { Pada pasien COVID- } \\
19 \text { dengan hipertensi } \\
\text { rawat inap, } \\
\text { penggunaan } \\
\text { ACEI/ARB berhu- } \\
\text { bungan dengan } \\
\text { penurunan risiko } \\
\text { mortalitas diban- } \\
\text { dingkan yang tidak } \\
\text { menggunakan } \\
\text { ACEI/ARB }\end{array}$ \\
\hline 2 & $\begin{array}{l}\text { Harmony } \\
\text { R. } \\
\text { Reynolds } \\
\text { et al. (New } \\
\text { York, } \\
\text { USA) }\end{array}$ & $\begin{array}{l}\text { Studi } \\
\text { observa } \\
\text { sional }\end{array}$ & $\begin{array}{l}\text { - Total Pasien } \\
=12.594 \\
\text { - Pasien } \\
\text { COVID-19= } \\
5894 \\
\text { - Pasien } \\
\text { Hipertensi = } \\
4357 \\
\text { - Pasien } \\
\text { Hipertensi } \\
\text { dan COVID- } \\
19=2573\end{array}$ & 41,5 & 49 & $\begin{array}{l}\text { - } \mathrm{ACEI} / \mathrm{A} \\
\mathrm{RB}= \\
1019 \\
-\mathrm{Non}= \\
986\end{array}$ & $\begin{array}{l}\text { - Gagal jantung } \\
\text { - Infark miokard } \\
\text { - Diabetes } \\
\text { - Penyakit ginjal } \\
\text { kronik } \\
\text { - Penyakit paru } \\
\text { obtruktif }\end{array}$ & $\begin{array}{l}\text { Tidak ada efek yang } \\
\text { merugikan dari } \\
\text { penggunaan obat- } \\
\text { obatan golongan } \\
\text { penghambat sistem } \\
\text { SRAA pada pasien } \\
\text { COVID-19 dengan } \\
\text { hipertensi. }\end{array}$ \\
\hline 3 & $\begin{array}{l}\text { Juan Meng } \\
\text { et al } \\
\text { (Cina) }^{14}\end{array}$ & $\begin{array}{l}\text { Studi } \\
\text { retro- } \\
\text { spektif }\end{array}$ & $\begin{array}{l}- \text { Pasien } \\
\text { COVID-19= } \\
417 \\
\text { - Pasien } \\
\text { Hipertensi } \\
\text { dan COVID- } \\
19=42\end{array}$ & 57,1 & 64,5 & $\begin{array}{l}\text { - } \mathrm{ACEI} / \mathrm{A} \\
\mathrm{RB}=17 \\
-\mathrm{Non}=25\end{array}$ & $\begin{array}{l}\text { - DM tipe } 2 \\
\text { - Penyakit jantung } \\
\text { koroner }\end{array}$ & $\begin{array}{l}\text { SRAA inhibitor } \\
\text { meningkatkan luaran } \\
\text { klinik pada pasien } \\
\text { COVID-19 dengan } \\
\text { hipertensi. } \\
\text { Penggunaan secara } \\
\text { persisten dapat } \\
\text { bermanfaat bagi } \\
\text { pasien. }\end{array}$ \\
\hline 4 & $\begin{array}{l}\text { Diego } \\
\text { Lo'pez } \\
\text { Otero et al } \\
\text { (Spanyol) } \\
15\end{array}$ & $\begin{array}{l}\text { Retrosp } \\
\text { ektif, } \\
\text { single- } \\
\text { center }\end{array}$ & $\begin{array}{l}\text { - Pasien } \\
\text { COVID-19= } \\
965\end{array}$ & 44,04 & 59,5 & $\begin{array}{l}-\mathrm{ACEI} / \mathrm{A} \\
\mathrm{RB}= \\
213 \\
-\mathrm{Non}= \\
755\end{array}$ & $\begin{array}{l}\text { - Penyakit ati } \\
\text { - Penyakit paru } \\
\text { - Kanker } \\
\text { - Hipotiroidisme } \\
\text { - Penyakit } \\
\text { autoimun }\end{array}$ & $\begin{array}{l}\text { Riwayat pengobatan } \\
\text { ACEI/ARB pada } \\
\text { pasien COVID-19 } \\
\text { tidak memiliki efek } \\
\text { pada mortalitas pa } \\
\text { sien, risiko gagal } \\
\text { jantung, rawat inap } \\
\text { ataupun perawatan di } \\
\text { ICU. }\end{array}$ \\
\hline 5 & $\begin{array}{l}\text { Zheyong } \\
\text { Huang et al } \\
\text { (Wuhan, } \\
\text { Cina) }{ }^{16}\end{array}$ & $\begin{array}{l}\text { Studi } \\
\text { observa } \\
\text { sional }\end{array}$ & $\begin{array}{l}\text { Pasien } \\
\text { COVID-19 } \\
\text { dan } \\
\text { Hipertensi = } \\
50\end{array}$ & 54 & $\begin{array}{l}-\mathrm{ACE} \\
\mathrm{I} / \mathrm{AR} \\
\mathrm{B}= \\
52,65 \\
- \text { Non } \\
= \\
67,77\end{array}$ & $\begin{array}{l}\text { - } \mathrm{ACEI} / \mathrm{A} \\
\mathrm{RB}=20 \\
\text { - } \mathrm{Non}=30\end{array}$ & $\begin{array}{l}\text { - Diabetes melitus } \\
\text { - Penyakit arteri } \\
\text { koroner } \\
\text { - Penyakit paru } \\
\text { obstruktif kronik } \\
\text { - Anemia }\end{array}$ & $\begin{array}{l}\text { Setelah di obseravsi } \\
\text { tidak ada perbedaan } \\
\text { yang bermakna pada } \\
\text { karakteristik klinik } \\
\text { antara grup yang di- } \\
\text { terapi dengan SRAA } \\
\text { dan yang tidak. Data } \\
\text { ini merekomen- } \\
\text { dasikan ACEI/ARB } \\
\text { bisa saja mempunyai } \\
\text { sedikit efek dalam } \\
\text { meningkatkan }\end{array}$ \\
\hline
\end{tabular}




\begin{tabular}{|c|c|c|c|c|c|c|c|c|}
\hline 6 & $\begin{array}{l}\text { Chao Gao } \\
\text { dkk. } \\
\text { (Wuhan, } \text { Cina) }{ }^{17}\end{array}$ & $\begin{array}{l}\text { Studi } \\
\text { observa } \\
\text { sional- } \\
\text { retrospe } \\
\text { ktif }\end{array}$ & $\begin{array}{l}- \text { Pasien } \\
\text { COVID-19= } \\
2877 \\
\text { - } \text { Pasien } \\
\text { Hipertensi = } \\
850\end{array}$ & 51,09 & $\begin{array}{l}-\mathrm{ACE} \\
\mathrm{I} / \mathrm{AR} \\
\mathrm{B}= \\
62,64 \\
-\mathrm{Non} \\
= \\
64,84\end{array}$ & $\begin{array}{l}\text { - } \mathrm{ACEI} / \mathrm{A} \\
\mathrm{RB}= \\
183 \\
\text { - } \mathrm{Non}= \\
527\end{array}$ & $\begin{array}{l}\text { - Diabetes Melitus } \\
\text { - Angina miokard } \\
\text { - Miokard infark } \\
\text { - Penyakit arteri } \\
\text { perifer } \\
\text { - Penyakit jantung } \\
\text { kronik } \\
\text { - Stroke } \\
\text { - Gagal ginjal } \\
\text { - PPOK } \\
\text { - Pneumonia } \\
\text { - Obstructive sleep } \\
\text { - Apnoea } \\
\text { - Asma } \\
\text { - Kanker }\end{array}$ & $\begin{array}{l}\text { kemungkinan kondisi } \\
\text { buruk dari COVID- } \\
19 . \\
\text { Tidak dilanjutkannya } \\
\text { terapi anti-hipertensi } \\
\text { diduga akan ber } \\
\text { kaitan dengan pening } \\
\text { katan risiko morta } \\
\text { litas. Tidak mene } \\
\text { mukan efek meru } \\
\text { gikan dari peng } \\
\text { gunaan penghambat } \\
\text { SRAA terhadap } \\
\text { pasien COVID-19. }\end{array}$ \\
\hline 7 & $\begin{array}{l}\text { Nian Di- } \\
\text { Tan et al } \\
(\text { Wuhan, } \\
\text { Cina) })^{18}\end{array}$ & $\begin{array}{l}\text { Studi } \\
\text { cohort- } \\
\text { retrospe } \\
\text { ktif }\end{array}$ & $\begin{array}{l}\text { - } \text { Pasien } \\
\text { COVID-19 = } \\
204 \\
\text { - } \text { Pasien } \\
\text { Hipertensi = } \\
100\end{array}$ & 51 & $\begin{array}{l}-\mathrm{ACE} \\
\mathrm{I} / \mathrm{AR} \\
\mathrm{B}= \\
67 \\
-\mathrm{Non} \\
= \\
67,5\end{array}$ & $\begin{array}{c}\text { - } \mathrm{ACEI} / \mathrm{A} \\
\mathrm{RB}=31 \\
-\mathrm{Non}=69\end{array}$ & $\begin{array}{l}\text { - Penyakit } \\
\text { gastrointestinal } \\
\text { - PPOK } \\
\text { - Penyakit jantung } \\
\text { koroner } \\
\text { - Diabetes melitus } \\
\text { - Penyakit ginjal } \\
\text { kronik }\end{array}$ & $\begin{array}{l}\text { Penggunaan ACEI/ } \\
\text { ARB pada pasien } \\
\text { rawat inap mengu } \\
\text { rangi risiko morta } \\
\text { litas dan risiko gejala } \\
\text { gastrointestinal. }\end{array}$ \\
\hline 8 & $\begin{array}{l}\text { Francisco J } \\
\text { de Abajo et } \\
\text { al } \\
\text { (Spanyol) } \\
19\end{array}$ & $\begin{array}{l}\text { Studi } \\
\text { populasi } \\
\text {-kasus }\end{array}$ & $\begin{array}{l}\text { - } \text { Pasien } \\
\text { COVID-19= } \\
1139 \\
\text { - Pasien } \\
\text { Hipertensi = } \\
617\end{array}$ & 61 & 69,1 & $\begin{array}{l}\text { - } \mathrm{ACEI} / \mathrm{A} \\
\mathrm{RB}= \\
497 \\
\text { - } \mathrm{Non}= \\
155\end{array}$ & $\begin{array}{l}\text { - Diabetes melitus } \\
\text { - Dislipidemia } \\
\text { - Penyakit jantung } \\
\text { iskemik } \\
\text { - Gagal jantung } \\
\text { - Atrial fibrilasi } \\
\text { - Penyakit } \\
\text { tromboembolik } \\
\text { - Kejadian } \\
\text { serebrovaskuler } \\
\text { - PPOK } \\
\text { - Asma } \\
\text { - Kanker } \\
\text { - PGK }\end{array}$ & $\begin{array}{l}\text { Penghambat SRAA } \\
\text { tidak meningkatkan } \\
\text { risiko terjangkit } \\
\text { COVID-19 termasuk } \\
\text { tidak meningkatkan } \\
\text { kejadian penyakit } \\
\text { yang lebih berat, ke } \\
\text { ICU. Sebaliknya } \\
\text { harus diteruskan un } \\
\text { tuk mencegah kasus } \\
\text { berat COVID-19. }\end{array}$ \\
\hline 9 & $\begin{array}{l}\text { Anton De } \\
\text { Spiegeleer } \\
\text { et al } \\
\left(_{\text {Belgia) }}^{20}\right.\end{array}$ & $\begin{array}{l}\text { Studi } \\
\text { cohort- } \\
\text { retrospe } \\
\text { ktif }\end{array}$ & $\begin{array}{l}\text { - } \text { Pasien } \\
\text { COVID-19= } \\
154 \\
\text { - } \text { Pasien } \\
\text { Hipertensi = } \\
39\end{array}$ & 33 & 85,9 & $\begin{array}{r}\text { - } \mathrm{ACEI} / \mathrm{A} \\
\mathrm{RB}=30 \\
-\mathrm{Non}= \\
124\end{array}$ & - Diabetes Melitus & $\begin{array}{l}\text { Tidak ada hubungan } \\
\text { secara statistik antara } \\
\text { penggunaan ACEI/ } \\
\text { ARB dengan status } \\
\text { asimtomatik ataupun } \\
\text { kejadian kasus berat. }\end{array}$ \\
\hline 10 & $\begin{array}{l}\text { David J. } \\
\text { Bae et al. } \\
(\text { Los } \\
\text { Angeles) })^{21}\end{array}$ & $\begin{array}{l}\text { Studi } \\
\text { cohort- } \\
\text { retrospe } \\
\text { ktif }\end{array}$ & $\begin{array}{l}\text { - Pasien } \\
\text { COVID-19 = } \\
590 \\
\text { - Pasien } \\
\text { Hipertensi = } \\
150\end{array}$ & 48,8 & 46 & $\begin{array}{l}\text { - } \mathrm{ACEI} / \mathrm{A} \\
\mathrm{RB}=78 \\
\text { - } \mathrm{Non}= \\
512\end{array}$ & $\begin{array}{l}\text { - Penyakit jantung } \\
\text { koriner } \\
\text { - Miokard infark } \\
\text { - Penyakit arteri } \\
\text { perifer } \\
\text { - Stroke } \\
\text { - Kardiomiopati } \\
\text { - Gagal jantung } \\
\text { - Atrial fibrilasi } \\
\text { - Dilipidemia } \\
\text { - Diabetes melitus } \\
\text { - Hipotiroidisme } \\
\text { - PPOK } \\
\text { - PGK } \\
\text { - Kanker } \\
\text { - Penyakit } \\
\text { imunologi } \\
\text { - Penyakit } \\
\text { - } \text { Pematologi } \\
\text { Penyakit } \\
\text { reumatologi }\end{array}$ & $\begin{array}{l}\text { Diantara pasien } \\
\text { dengan diagnosis } \\
\text { COVID-19, peng- } \\
\text { gunaan ACEI/ARB } \\
\text { tidak memiliki } \\
\text { hubungan dengan } \\
\text { peningkatan risiko } \\
\text { masuk rumah sakit. } \\
\text { Penggunaan lanjut } \\
\text { ACEI/ARB dianggap } \\
\text { aman. }\end{array}$ \\
\hline
\end{tabular}




\section{BAHASAN}

Berdasarkan hasil penelitian dari literatur yang telah dikaji, mayoritas literatur tersebut menunjukkan bahwa tidak ada pengaruh penggunaan ACEI dan ARB sebagai pilihan terapi hipertensi pada pasien COVID-19. Beberapa literatur juga berpendapat bahwa penggunaan ACEI dan ARB pada pasien COVID-19 dengan hipertensi memiliki efek yang baik dalam menurunkan mortalitas serta progresifitas dari penyakit. ACEI memiliki target kerja pada ACE-1 untuk mencegah perubahan angiotensin I menjadi angiotensin II dan ARB yang bekerja pada angiotensin II yang diubah dari angiotensin I oleh ACE-1. ACE-1 memiliki homolog dengan ACE-2 yang merupakan reseptor target dari SARS-CoV-2 dan SARS-CoV dalam menginfeksi manusia. ACE-2 merupakan suatu reseptor yang banyak terdapat pada endotel vaskular dan paru-paru, terutama pada endotel dan sel epitel alveolus tipe 2. ${ }^{22}$ SARS-CoV dan SARS-CoV-2 akan mengikat ACE-2 kemudian mengaktivasi transmembrane serine protease-2 (TMPRSS2), yang umumnya banyak terdapat dalam paru-paru. ${ }^{22} \mathrm{Hal}$ tersebut memungkinkan penyatuan virus melalui envelope protein-nya dan membran sel, yang kemudian membuat virus melakukan penetrasi dan replikasi di dalam sel. ${ }^{23}$ ACE-1 dan ACE-2 masing-masing akan memecah peptida angiotensin. ACE-1 memecah dipeptida histidin dan leusin dari angiotensin I yang kemudian mengubahnya menjadi angiotensin II yang selanjutnya menyebabkan efek vasokonstriksi, broncokonstriksi, peningkatan permeabilitas vaskular, inflamasi, dan fibrosis serta risiko ARDS melalui angiotensine II type 1 receptor $\left(\mathrm{AT}_{1} \mathrm{R}\right){ }^{22}$ Angiotensine II type 2 receptor $\left(\mathrm{AT}_{2} \mathrm{R}\right)$ dan $G$ protein-coupled receptor (MasR) memiliki kerja yang sebaliknya dari $\mathrm{AT}_{1} \mathrm{R}$ dan golongan obat $\mathrm{ARB}$ secara spesifik bekerja dengan memblokade jalur angiotensin II/AT $\mathrm{AR}_{1}{ }^{22}$

ACE-2 akan memecah salah satu asam amino (leusin atau fenilalanin) dari angiotensin I menjadi angiotensin (1-9) dan dari angiotensin II menjadi angiotensin (1-7). ${ }^{21}$ Delesi genetik dari ACE-2 dapat memper- buruk ARDS dan angiotensin (1-7), ACEI atau ARB dapat memperbaikinya. ${ }^{22}$ Penelitian menunjukkan bahwa mengurangi jalur ACE-1/angiotensin II/AT $\mathrm{A}_{1} \mathrm{R}$ dan meningkatkan jalur ACE-1/angiotensin II/AT ${ }_{2} \mathrm{R}$ atau ACE-2/angiotensin (1-7)/AT ${ }_{2} \mathrm{R}$ atau ACE2/angiotensin (1-7)/MasR dapat men-cegah ARDS karena patogen infeksius termasuk di dalamnya coronavirus. ${ }^{22}$ Oleh karena itu, mengurangi efek angiotensin II dengan menggunakan ACEI dan ARB serta meningkatkan jalur ACE-2 memiliki manfaat yang baik pada infeksi SARS-CoV-2. ${ }^{22}$

\section{SIMPULAN}

Penggunaan obat golongan penghambat SRAA dalam hal ini angiotensin converting enzyme inhibitor (ACEI) dan angiotensin receptor blockers (ARB) sebagai terapi pada COVID-19 dengan hipertensi tidak memengaruhi luaran, mortalitas, maupun progresifitas penyakit. Sebaliknya, penggunaan ACEI dan ARB dapat memiliki manfaat dalam menurunkan mortalitas dan luaran pasien COVID-19 dengan hipertensi.

\section{Konflik Kepentingan}

Penulis menyatakan tidak terdapat konflik kepentingan dalam studi ini.

\section{DAFTAR PUSTAKA}

1. Adrian TSJ. Hipertensi esensial : diagnosis dan tatalaksana terbaru pada dewasa. Cermin Dunia Kedokt. 2019;46(3):172-8.

2. Kemenkes.RI. Pusdatin Hipertensi. Infodatin. 2014;(Hipertensi):1-7.

3. Pedoman Pencegahan dan Pengendalian Coronavirus Disease 2019 (COVID-19). Jakarta: Kementerian Kesehatan, 2020.

4. Coronavirus Disease (COVID-19) Weekly Epidemiological Update Global Epidemiological Situation. Available from https://www.who.int/publications/ $\mathrm{m} /$ item/weekly-epidemiologicalupdate---31-august-2020

5. Gugus Tugas Percepatan Penanganan COVID19. [cited 2020 Aug 31]. Available from https://covid19.go.id/

6. Website Pemantauan Covid-19 | Pemerintah Sulawesi Utara. [cited 2020 Aug 31]. Available from https://corona.sulutprov. go.id/ 
7. Huang C, Wang Y, Li X, Ren L, Zhao J, Yi H, et al. Clinical features of patients infected with 2019 novel coronavirus in Wuhan, China. Lancet. 2020;395 (10223):497-506.

8. Schiffrin EL. Hypertension and COVID-19. Am J Hypertens. 2020:33(5):373-9

9. Tsolaki V, Zakynthinos GE, Mantzarlis K, Prof DM. Increased mortality among hypertensive COVID-19 patients: Pay a closer look on diuretics in mechanically ventilated patients. Heart Lung. 2020; 000:1-2.

10. Zheng YY, Ma YT, Zhang JY, Xie X. COVID-19 and the cardiovascular system. Nat Rev Cardiol. 2020;17(5): 259-60.

11. Williams B, Zhang Y. Hypertension, renin angiotensin - aldosterone system inhibition, and COVID-19. Lancet. 2020;395 (10238):1671-1673.

12. Zhang P, Zhu L, Cai J, Lei F, Juan JQ, Xie J, et al. Association of inpatient use of angiotensin-converting enzyme inhibitors and angiotensin II receptor blockers with mortality among patients with hypertension hospitalized with COVID19. Circ Res. 2020:126(12):1671-81.

13. Reynolds HR, Adhikari S, Pulgarin C, Troxel $\mathrm{AB}$, Iturrate $\mathrm{E}$, Johnson $\mathrm{SB}$, et al. Renin-angiotensin-aldosterone system inhibitors and risk of covid-19. N Engl J Med. 2020;382(25):2441-8.

14. Meng J, Xiao G, Zhang J, He X, Qu M, Bi J, et al. Renin-angiotensin system inhibitors improve the clinical outcomes of COVID-19 patients with hypertension. Emerg Microbes Infect. 2020;9(1):75760.

15. López-Otero D, López-Pais J, Cacho-Antonio CE, Antunez-Muinos PJ, GonzalezFerreiro T, Perez-Posa M, et al. Impact of angiotensin-converting enzyme inhibitors and angiotensin receptor blockers on COVID-19 in a western population. CARDIOVID registry. Rev Española Cardiol (English Ed. 2020;(x). Doi. 10.1016/j.rec.2020.05.018.

16. Huang Z, Cao J, Yao Y, Jin X, Luo Z, Xue Y, et al. The effect of RAS blockers on the clinical characteristics of COVID-19 patients with hypertension. Ann Transl Med. 2020;8(7):430-430.

17. Gao C, Cai Y, Zhang K, Zhou Y, Zhang Y, Zhang $X$, et al. Association of hypertension and antihypertensive treatment with COVID-19 mortality: a retrospective observational study. Eur Heart J. 2020;41(22):2058-66.

18. Tan N-D, Qiu Y, Xing X-B, Ghosh S, Chen M-H, Mao R. Associations between angiotensin-converting enzyme inhibitors and angiotensin ii receptor blocker use, gastrointestinal symptoms, and mortality among patients with COVID19. Gastroenterology. 2020;159(3): 1170-2.e1.

19. de Abajo FJ, Rodríguez-Martín S, Lerma V, Mejia-Abril G, Aguilar M, GarciaLuque $\mathrm{A}$, et al. Use of renin-angiotensin-aldosterone system inhibitors and risk of COVID-19 requiring admission to hospital: a case-population study. Lancet. 2020;395(10238):1705-14.

20. De Spiegeleer A, Bronselaer A, Teo JT, De Tre G, Belmans L, Byttebier G, et al. The effects of ARBs, ACEis, and statins on clinical outcomes of COVID-19 infection among nursing home residents. $\mathrm{J}$ Am Med Dir Assoc. 2020; 21(7):90914.e2.

21. Bae DJ, Tehrani DM, Rabadia SV, Frost M, Parikh BV, Calfon-Press $\mathrm{M}$, et al. Angiotensin converting enzyme inhibitor and angiotensin ii receptor blocker use among outpatients diagnosed with COVID-19. Am J Cardiol. 2020;132: 150-7.

22. Rossi GP, Sanga V, Barton M. Potential harmful effects of discontinuing aceinhibitors and arbs in covid-19 patients. Elife. 2020;9:1-8.

23. Kai H, Kai M. Interactions of coronaviruses with ACE2, angiotensin II, and RAS inhibitors - lessons from available evidence and insights into COVID-19. Hypertens Res. 2020;43(7):648-54. 